\title{
HEALTH BELIEF MODEL ON PSYCHOSOCIAL FACTORS INFLUENCING HIV/AIDS PREVENTION BEHAVIOR ON LESBIAN COMMUNITY IN SURAKARTA
}

\author{
Maria Paula Marla Nahaki1), Argyo Demartoto²), Bhisma Murti1 ${ }^{1}$ \\ 1)Masters Program in Public Health, Sebelas Maret University \\ 2)Faculty of Social and Political Sciences, Sebelas Maret University
}

\begin{abstract}
Background: HIV/AIDS keeps on becoming a global problem. Even though there are some scientific breakthroughs on the disease and how to prevent, most people are still under the risk to contract it. The number of HIV/AIDS incidences on lesbian is still low, up to the point of considering them as low risk. This study aimed to analyze Health Belief Model on the psychosocial factors that influence HIV/AIDS prevention behavior in lesbian community in Surakarta.
\end{abstract}

Subjects and Method: This was an analytic qualitative study with phenomenology approach, conducted at Talita Kum Community, Surakarta. Key informant in this study was the Head of Talita Kum Community, with their members as main informants, and supporting informants from the health workers, Non-Government Organization and Regional Commission on AIDS Prevention (KPAD), selected by purposive and snowball sampling. The data were collected by in-depth interview, non-participating observation, and document review. The data were analyzed by Miles and Huberman method.

Results: The lesbian community in Surakarta is quite knowledgeable on the HIV/AIDS concept. But they still did not have enough understanding of how to prevent it. This could be very beneficial to lessen the chance of HIV from spreading and evolving into AIDS. The study result stated that the lesbian community did not consider themselves to be on the risk. Therefore, they lack the preventing method. However, bisexual woman considered herself to be at high risk; therefore, she regularly conducted medical check-up.

Conclusion: The knowledge of HIV/AIDS risk factors on lesbian have to be socialized so they could take the proper prevention steps.

Keywords: lesbian, health belief model, psychosocial factor

Correspondence: Maria Paula Marla Nahak. Masters Program in Public Health, Sebelas Maret University, Surakarta. Email:

marlanahak858@gmail.com. Mobile:+6282328282282. 